\title{
Concurrent Chemoradiotherapy in Locally Advanced Esophageal Cancer
}

\author{
Sang Jun Byun, M.D.*, Jin Hee Kim, M.D.*, Ok Bae Kim, M.D.* and Hong Suk Song, M.D. ${ }^{\dagger}$ \\ Departments of ${ }^{\star}$ Radiation Oncology and ${ }^{\dagger}$ Internal Medicine, Dongsan Medical Center, \\ Keimyung University School of Medicine, Daegu, Korea
}

\begin{abstract}
Purpose: This study was designed to evaluate the results of local control, survival rate, prognostic factors, and failure pattern in locally advanced esophageal cancer.

Materials and Methods: We retrospectively studied 50 patients with locally advanced esophageal cancer treated with concurrent chemoradiotherapy at Keimyung University Dongsan Medical Center from June of 1999 to August of 2008. Seven patients with inappropriate data were excluded, and 43 patients were analyzed. There were 39 males and four female patients ranging in age from 43 to 78 years (median, 63 years). There were seven patients with stage IIA and 36 with stage III. Irradiation from 46 Gy to 63 Gy (median, 54 Gy) was carried out 5 days per week, 1.8 Gy once a day. There were eight patients with neo-adjuvant chemotherapy, and we mostly used 5-fluorouracil, cisplatin with 3 cycles for concurrent chemotherapy. The range of follow up periods was from 2 to 82 months (median, 15.5).

Results: There were nine patients that exhibited a complete response, 23 that exhibited a partial response, 9 that exhibited no response, and 2 that exhibited disease progression. The median survival time was 15 months. Two-year and 5-year survival rates were $36.5 \%$ and $17.3 \%$, respectively. Two-year and 5-year disease-free survival rates were $32.4 \%$ and $16 \%$, respectively. Treatment failure occurred in 22 patients (51.2\%). Patterns of failure were categorized as local failure in 18 patients and distant metastasis in four patients. In a univariate analysis for prognostic factors related to overall survival and disease-free survival, the hemoglobin levels during chemoradiotherapy ( $\geq 12$ vs. $<12, p=0.02 / p=0.1$ ) and the response to the treatments (CR/PR vs. NR/PD, $\mathrm{p}=0.002 / \mathrm{p}<0.0001$ ) were statistically significant. In a multivariate analysis, only response to the treatments was revealed to be statistically significant. There was no statistical significance associated with patient age, gender, disease stage, T-stage, smoking history, tumor location, or neo-adjuvant chemotherapy.

Conclusion: Our survival rate was similar to those of other institutions. Local recurrence was the main reason for failure. It is suggested that further prospective studies should be performed to improve local control.
\end{abstract}

Key Words: Esophageal cancer, Concurrent chemoradiotherapy, Survival rate, Prognostic factor, Failure

\section{Introduction}

Squamous cell carcinoma in the esophagus is a lethal disease with poor prognosis. It is related to a lymphatic spreading pattern with defects in serosal lining, frequent direct extension into surrounding structures, and even metastasis. ${ }^{1)}$

In the past decades, surgery after diagnosis of the disease in a locally-advanced state was a standard therapeutic option and

Submitted November 17, 2010, accepted January 19, 2011

Reprint requests to Jin Hee Kim, M.D., Department of Radiation Oncology, Dongsan Medical Center, Keimyung University, 194 Dongsan-dong, Jung-gu, Daegu 700-712, Korea

Tel: 053)250-7665, Fax: 053)250-7984

E-mail: jhkim@dsmc.or.kr reported to have low curative rates. There were also several reports to demonstrate better outcomes with postoperative radiotherapy than those with surgery alone. ${ }^{2 \sim 4)}$ DeMeester and Barlow $^{2)}$ suggested that improvement of survival rates might be expected because microscopic tumor after surgery could be eradicated by radiotherapy. The use of chemotherapy followed by surgery had proven to be not effective for preventing distant metastasis or local failure in esophageal cancer. ${ }^{5)}$ There were also several trials assessing the effect of preoperative radiotherapy, but there was no clear benefit regarding survival in case of locally-advanced esophageal cancer.)

Recently, concurrent chemoradiotherapy has been associated with more favorable outcomes for locally-advanced esophageal 
cancer because it can improve local control and combat micrometastases simultaneously. Chemotherapeutic agents like cisplatin and 5-fluorouracil (5-FU) are typically used as radiosensitizers and impart anti-tumor effects. ${ }^{7,8)}$

A phase III trial in the United States, Radiation Therapy Oncology Group (RTOG) 85-019) revealed that the addition of chemotherapy to radiation therapy is superior to radiation therapy alone. Furthermore, concurrent chemoradiotherapy has become a standard of treatment for locally-advanced esophageal cancer.

This study was designed to retrospectively evaluate the local control, survival rate, prognostic factors and failure patterns in locally-advanced esophageal cancer treated with concurrent chemoradiotherapy in our institution.

\section{Materials and Methods}

We retrospectively studied 50 patients with locally-advanced esophageal cancer treated with concurrent chemoradiotherapy at Keimyung University Dongsan Medical Center from June of 1999 to August of 2008. Patients underwent physical examination, complete blood cell count, chest X-ray, chest high resolution computed tomography, positron emission tomography computed tomography (PET-CT), and endoscopic biopsies to confirm the presence of disease and evaluate the clinical stage. PET-CT scan was performed since March of 2007 in our institution and only eight patients underwent PET-CT for clinical staging. The patients were grouped according to the AJCC TNM 6th edition staging method. The eligibility criteria for locally-advanced disease were stage T1N1M0 or T2-4, any N, M0. Periods for evaluating treatment outcomes were calculated from the first day of radiotherapy.

Two patients without regular follow-up after completion of concurrent chemoradiotherapy and five patients for whom we could not confirm treatment results due to the absence of appropriate follow-up examination were excluded from this study; in total, 43 patients were analyzed in our study. The patients' characteristics are presented in Table 1. There were 39 males and four female patients with a range of age from 43 to 78 years old (median, 63 years). There were seven patients with stage IIA and 36 with stage III. All patients were squamous cell carcinoma in pathology. The performance
Table 1. Patients Characteristics

\begin{tabular}{lc}
\hline \multicolumn{1}{c}{ Characteristics } & Values \\
\hline Age & $43 \sim 78$ (median 63) \\
Gender & 39 \\
Male & 4 \\
Female & \\
Pathology - Squamous cell carcinoma & 4 \\
Well differentiated & 16 \\
Moderately differentiated & 5 \\
Poorly differentiated & 18 \\
Unknown & \\
Stage & 7 \\
IIA & 36 \\
III & \\
Performance status & 22 \\
ECOG* 0 & 21 \\
ECOG 1 & \\
Radiation therapy dose (Gy) & 6 \\
$<54$ & 37 \\
Z54 & \\
T-stage & 5 \\
T2 & 17 \\
T3 & 21 \\
T4 & \\
N-stage & 1 \\
Nx & 10 \\
N0 & 32 \\
N1 & \\
Tumor location & 26 \\
Cervical & \\
Upper thoracic & \\
Middle thoracic & \\
Lower thoracic & \\
& \\
&
\end{tabular}

*Eastern Cooperative Oncology Group.

status before the treatments was Eastern Cooperative Oncology Group (ECOG). 0 in 22 patients and ECOG 1 in 21 patients. In radiation therapy planning, a margin of $5 \mathrm{~cm}$ above and below the GTV and $1.5-\mathrm{cm}$ radial margin are usually applied to cover subclinical disease. The margin was reduced to $2 \mathrm{~cm}$ in above and below the GTV and $1 \mathrm{~cm}$ in radial margin after 45 Gy. Two-dimensional technique was applied for 28 patients until December of 2004 with anteroposterior (AP)-posteroanterior (PA) bilateral opposing fields up to 41.4 Gy and more than two fields to shield spinal cord for remaining dose. Three-dimensional conformal technique was used since Jan of 2005 for 15 patients. Forty-six Gy to 63 Gy of radiation was delivered with 6/10/15 MV photons (median, 54 Gy) for 5 days per week and 1.8 Gy once a day.

There were eight patients who underwent concurrent chemoradiotherapy 4 weeks after completion of neo-adjuvant chemotherapy. Six patients were treated with 5-FU/cisplatin 
Table 2. Chemotherapeutic Regimens

\begin{tabular}{lc}
\hline \hline \multicolumn{1}{c}{ Chemotherapy } & No. (\%) \\
\hline Neo-adjuvant CTx ${ }^{*}$ regimens & \\
5-FU ${ }^{\dagger} /$ cisplatin & $6(75.0)$ \\
Paclitaxel/cisplatin & $2(25.0)$ \\
Total & $8(100)$ \\
Concurrent CTx regimens & $37(86.0)$ \\
5-FU/cisplatin & $3(7.0)$ \\
Docetaxel/cisplatin & $2(4.7)$ \\
Paclitaxel/cisplatin & $1(2.3)$ \\
5-FU only & $43(100)$ \\
Total & \\
\hline
\end{tabular}

${ }^{*}$ chemotherapy, ${ }^{\dagger}$ 5-fluorouracil.

Table 3. Treatment Response

\begin{tabular}{lr}
\hline \multicolumn{1}{c}{ Response } & No. (\%) \\
\hline Complete response & $9(20.9)$ \\
Partial response & $23(53.5)$ \\
No response & $9(20.9)$ \\
Progression of disease & $2(4.7)$ \\
Total & $43(100)$ \\
\hline
\end{tabular}

and two patients were given paclitaxel/cisplatin before concurrent chemoradiotherapy. Concurrent chemoradiotherapy was administered, mainly 5-FU/cisplatin-based regimens with continuous infusion. 5 -FU $1,000 \mathrm{mg} / \mathrm{m}^{2}$ with $5 \%$ dextrose in water $500 \mathrm{~mL}$ was delivered, starting on days 1 to 4 as a continuous intravenous infusion. Cisplatin $75 \mathrm{mg} / \mathrm{m}^{2}$ with $0.9 \%$ normal saline $500 \mathrm{~mL}$ was delivered during 1 day with 3-week interval. Thirty-seven patients were treated with 5-FU/cisplatin and two of them were administered additional chemotherapy. One was given additional docetaxel/cisplatin, and another one patient was treated with paclitaxel/cisplatin. Three patients were treated with docetaxel/cisplatin and one of them received additional dose of 5-FU/cisplatin. Two patients were treated with paclitaxel/cisplatin and one of them received additional 5-FU/cisplatin treatment. The remaining 1 patient was administered only 5-FU (Table 2).

Follow-up chest CT scans or endoscopic examinations were performed at 1 to 3 months after completion of concurrent chemoradiotherapy. We used World Health Organization (WHO) criteria including complete response (CR), partial response (PR), no response (NR), and progression of disease (PD) for assessment after completion of concurrent chemoradiotherapy. ${ }^{10)}$ The range of follow-up periods was from 2 to

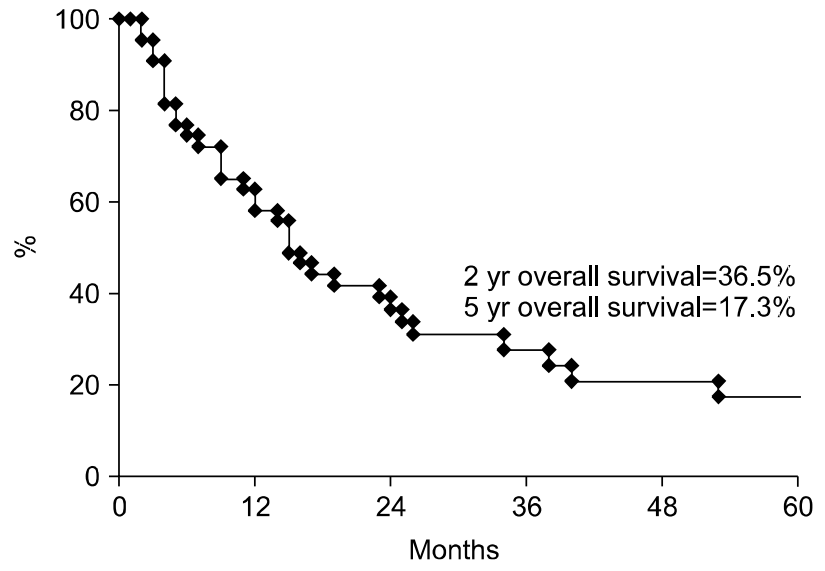

Fig. 1. Overall survival curve.

82 months with a median of 15.5 months. The time to local failure and distant metastases were analyzed from the starting day of any treatment modalities including neo-adjuvant chemotherapy and concurrent chemoradiotherapy after diagnosis.

The Kaplan-Meier method was used to estimate overall survival rates (OS) and disease-free survival rates (DFS). Univariate analysis evaluating factors associated with OS was performed by a log-rank test. Factors found to influence survival on univariate analysis were then analyzed by Cox proportional hazard regression analysis. Statistical analyses were performed with SPSS ver. 17.0 (SPSS Inc., Chicago, IL, USA).

\section{Results}

\section{Local control and survival}

As shown in Table 3, there were nine patients showing complete response (20.9\%), 23 presenting partial responses (53.5\%), nine showing no response (20.9\%), and two with disease $(4.7 \%)$. Two-year and 5-year overall survival rates were $36.5 \%$ and $17.3 \%$, respectively (Fig. 1). Two-year and 5 -year disease-free survival rates were $32.4 \%$ and $16 \%$, respectively (Fig. 2). The median survival of all patients was 15 months.

\section{Prognostic factor}

We analyzed several factors that may impact disease prognosis including patient age, gender, disease stage, smoking 
history, total radiation dose, prior treatments before concurrent chemoradiotherapy, hemoglobin level at the time of chemoradiotherapy, tumor location in the esophagus, response to treatment and absence or presence of neo-adjuvant

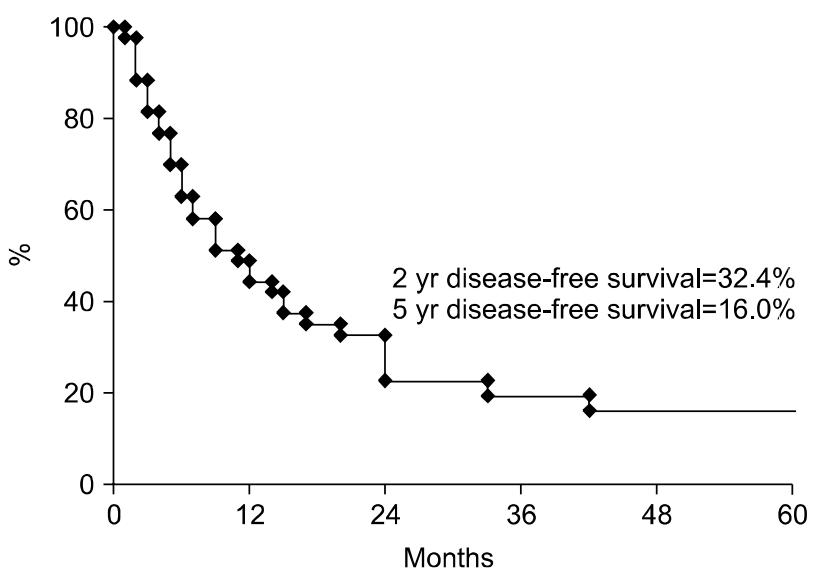

Fig. 2. Disease free survival curve. chemotherapy.

As shown in Table 4, on univariate analysis for identifying potential prognostic factors related to overall survival, hemoglobin level at the time of chemoradiotherapy ( $<12$ vs. $\geq 12, \mathrm{p}=0.02)$ and response to treatments $(\mathrm{CR} / \mathrm{PR}$ vs. NR/PD, $\mathrm{p}=0.002)$ were statistically significant (Fig. 3,4$)$ and the total dose of radiation therapy ( $<54$ Gy vs. $\geq 54 \mathrm{~Gy}, \mathrm{p}=0.06$ ) was marginally significant. On multivariate analysis, response to treatments was only found to be statistically significant $(95 \%$ confidence interval [CI], 1.289 to 7.595 ; hazard ratio [HR], 3.129; $\mathrm{p}=0.012$ ).

On univariate analysis for identifying potential prognostic factors related to disease-free survival, response to treatments $(\mathrm{CR} / \mathrm{PR}$ vs. NR/PD, $\mathrm{p}<0.0001)$ was statistically significant and hemoglobin level at the time of chemoradiotherapy $(<12$ vs. $\geq 12, p=0.1$ ) was marginally significant. On multivariate analysis, response to treatments was also found to be

Table 4. Univariate Analysis of Prognostic Factors Related to Overall Survival

\begin{tabular}{|c|c|c|c|c|c|c|c|c|}
\hline \multirow{2}{*}{ Values } & & \multirow{2}{*}{ No. } & \multicolumn{2}{|c|}{ Overall survival } & \multirow{2}{*}{$\mathrm{p}$-value } & \multicolumn{2}{|c|}{ Disease-free survival } & \multirow{2}{*}{ p-value } \\
\hline & & & $2 \mathrm{yr}$ & $5 \mathrm{yr}$ & & $2 \mathrm{yr}$ & $5 \mathrm{yr}$ & \\
\hline \multirow[t]{2}{*}{ Age } & $\leq 62$ & 19 & 36.8 & 12.6 & 0.814 & 24.1 & 16.1 & 0.172 \\
\hline & $>62$ & 24 & 36.5 & 21.9 & & 41.5 & 41.5 & \\
\hline \multirow[t]{2}{*}{ Gender } & Male & 39 & 35.6 & 18.2 & 0.602 & 35.8 & 29.8 & 0.585 \\
\hline & Female & 4 & 50.0 & 0 & & 0 & 0 & \\
\hline \multirow[t]{2}{*}{ Stage } & IIA & 7 & 68.6 & 0 & 0.43 & 35.7 & 0 & 0.589 \\
\hline & III & 36 & 30.1 & 22.6 & & 33.5 & 33.5 & \\
\hline \multirow[t]{3}{*}{ T-stage } & $\mathrm{T} 2$ & 5 & 75.0 & - & 0.981 & 30.0 & - & 0.251 \\
\hline & T3 & 17 & 100 & 56.3 & & 48.8 & 39.0 & \\
\hline & $\mathrm{T} 4$ & 21 & 85.7 & 57.1 & & 18.9 & 18.9 & \\
\hline \multirow[t]{2}{*}{ Smoking } & $(+)$ & 37 & 37.6 & 19.3 & 0.671 & 35.1 & 29.2 & 0.686 \\
\hline & $(-)$ & 6 & 25.0 & - & & 0 & - & \\
\hline \multirow[t]{4}{*}{ Performance status $\left(\mathrm{ECOG}^{*}\right)$} & 0 & 27 & 56.2 & 32.4 & 0.196 & 38.0 & 38.0 & 0.502 \\
\hline & 1 & 8 & 37.5 & - & & 18.8 & - & \\
\hline & 2 & 2 & 50.0 & - & & 50.0 & 0 & \\
\hline & 3 & 6 & 25.0 & - & & 33.3 & - & \\
\hline \multirow[t]{2}{*}{ Hemoglobin (g/dL) } & $<12$ & 15 & 20.0 & 13.3 & 0.02 & 23.6 & 23.6 & 0.1 \\
\hline & $\geq 12$ & 28 & 45.1 & 17.4 & & 38.1 & 28.6 & \\
\hline \multirow[t]{2}{*}{ Neo-adjuvant chemotherapy } & $(+)$ & 8 & 37.5 & 25.0 & 0.734 & 38.9 & 38.9 & 0.63 \\
\hline & $(-)$ & 35 & 36.1 & 14.6 & & 33.2 & 24.9 & \\
\hline \multirow[t]{2}{*}{ Chemotherapy regimen } & 5-FU ${ }^{\dagger} /$ cisplatin & 37 & 47.9 & 22.0 & 0.853 & 35.9 & 28.7 & 0.906 \\
\hline & Taxol/cisplatin & 5 & 53.3 & 26.7 & & 26.7 & 26.7 & \\
\hline \multirow[t]{4}{*}{ Tumor location } & Cervical & 2 & 50.0 & - & 0.548 & 0 & - & 0.274 \\
\hline & Upper thoracic & 2 & - & - & & - & - & \\
\hline & Middle thoracic & 26 & 34.6 & 18.5 & & 30.8 & 30.8 & \\
\hline & Lower thoracic & 13 & 46.2 & 23.1 & & 62.9 & 42.0 & \\
\hline \multirow[t]{2}{*}{ Radiotherapy dose (Gy) } & $<54$ & 6 & 16.7 & - & 0.06 & 20.0 & - & 0.417 \\
\hline & $\geq 54$ & 37 & 39.7 & 18.5 & & 35.5 & 29.6 & \\
\hline \multirow[t]{2}{*}{ Response } & $\mathrm{CR}^{\ddagger} / \mathrm{PR}^{\S}$ & 32 & 59.6 & 30.0 & 0.002 & 42.8 & 35.7 & $<0.0001$ \\
\hline & $\mathrm{NR}^{\|} / \mathrm{PD}^{\|}$ & 11 & 18.2 & 0 & & 9.1 & - & \\
\hline
\end{tabular}

${ }^{*}$ Eastern Cooperative Oncology Group, ${ }^{\dagger}$ fluorouracil, ${ }^{\dagger}$ complete response, ${ }^{\S}$ partial response, " no response, "progression of disease. 


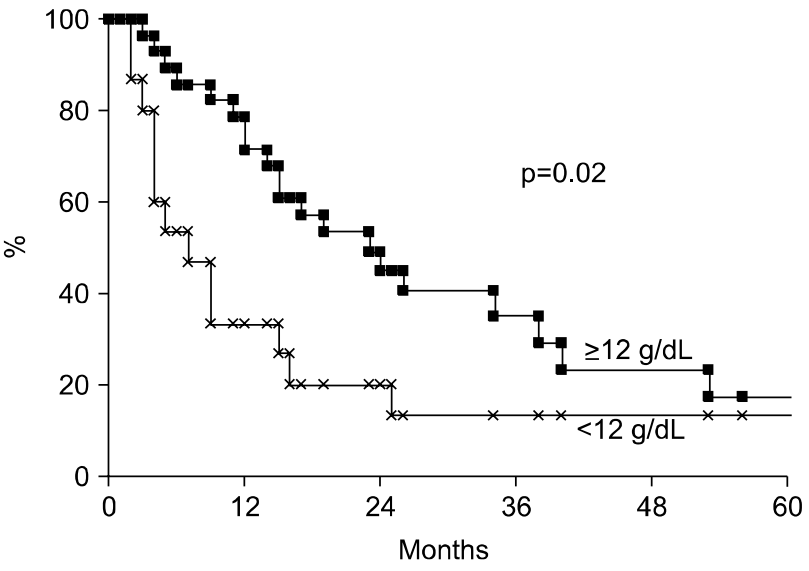

Fig. 3. Overall survival curves according to hemoglobin level.

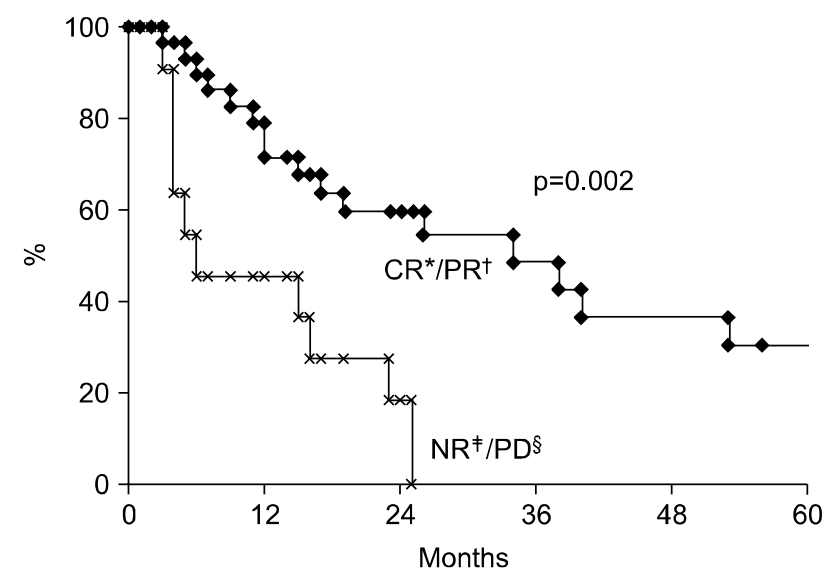

Fig. 4. Overall survival curves according to response after treatments. ${ }^{*}$ complete response, ${ }^{\dagger}$ partial response, ${ }^{\dagger}$ no response, ${ }^{\S}$ progression of disease.

statistically significant (95\% CI, 1.836 to 9.841; HR, 4.251; $\mathrm{p}=0.001$ ). There was no statistical significance associated with patient age, gender, disease stage, T-stage, smoking history, tumor location, or neo-adjuvant chemotherapy.

\section{Patterns of treatment failure}

There were 22 patients with recurring disease (51.2\%) and the patterns of the recurrence were separated to local failure in one patient among nine with complete response (2.3\%), local progression in 17 patients $(39.5 \%)$, and distant metastasis in four individuals $(9.3 \%)$, as shown in Table 5. Disease recurrence in the one patient with a complete response occurred 42 months after completion of concurrent chemoradiotherapy. There was no patient who had both local treatment failure and
Table 5. Patterns of Failure

\begin{tabular}{lc}
\hline \hline \multicolumn{1}{c}{ Type of failure } & No. $(\%)$ \\
\hline Recurrence after complete response & $1(2.3)$ \\
Local progression & $17(39.5)$ \\
Distant metastasis & $4(9.3)$ \\
Total & $22\left(51.2^{*}\right)$ \\
\hline
\end{tabular}

*percentage in all patients.

Table 6. Complications

\begin{tabular}{llc}
\hline \hline Complication & & No. (\%) \\
\hline Acute complication & Esophagitis & $5 / 43(11.6)$ \\
& Ulceration & $1 / 43(2.3)$ \\
Late complication & Stricture/obstruction & $12 / 43(27.9)$ \\
\hline
\end{tabular}

distant metastasis.

\section{Complications}

Endoscopic examination was performed 1 to 3 months after completion of concurrent chemoradiotherapy and five patients (11.6\%) developed esophagitis. Three patients were diagnosed at 2 months and two patients at 1 month following chemoradiotherapy. The one patient $(2.3 \%)$ with esophagitis after 1 month also suffered from ulcers.

Esophageal strictures and obstructions occurred in 12 patients (27.9\%) with dysphagia. Six patients were found to have strictures 2 months after treatment and two patients developed dysphagia after 1 month. Dysphagia was found in the four patients at 5, 6, 7, and 22 months following treatment by follow-up endoscopic examination (Table 6).

\section{Discussion and Conclusion}

Although there have been several trials conducted with the goal of improving survival of locally-advanced esophageal cancer, it is still challenging to expect better outcomes in these patients. Herskovic et al. ${ }^{11)}$ reported a $50 \%$ 1-year overall survival rate and 38\% 2-year overall survival rate, with a median survival period of 12.5 months in 121 locally-advanced esophageal cancer patients who received concurrent chemoradiotherapy. Smith et al. ${ }^{12)}$ also reported a $27 \%$ 2-year overall survival among 119 patients with stage I and II after concurrent chemoradiotherapy with a median survival period of 14.8 months. They also found improved overall survival in 
patients with locally-advanced esophageal cancer compared to those who received radiation therapy alone. Two-year and 5 -year overall survival rates were $27 \%$ and $9 \%$, respectively, in chemoradiotherapy group, and $12 \%$ and $7 \%$, respectively, in the group that only received radiation.

RTOG 85-01 showed that treatment with concurrent chemoradiotherapy resulted in significantly increased overall survival rates compared to radiotherapy alone in cases of locally-advanced esophageal cancer (T1-3 N0-1 M0). The overall survival rate for the concurrent chemoradiotherapy group at 5 years was $26 \%$ and $0 \%$ for the group that only received radiotherapy. ${ }^{9)}$ In our study, the overall survival rates at 2 years and 5 years were $36.5 \%$ and $17.3 \%$, respectively, with a median survival periods of 15 months, similar to outcomes of other trials. However, the distribution of patients according to disease stage was relatively uneven, seven patients were stage IIA and 36 were stage III. More reliable results would be obtained if the study had been conducted with a more uniform patients group.

There are several factors related to prognosis in esophageal cancer patients including disease stage, tumor location, tumor size, histologic type, gender, ethnicity, patient age, and response to treatment. Generally, tumor oxygenation is also considered to be of prognostic value and effect local control of tumors in locally-advanced cancers. ${ }^{13 \sim 17)}$ Many investigators also have reported that hemoglobin level before treatment is a valuable prognostic factor. ${ }^{18 \sim 21)}$ In our study, the pre-treatment hemoglobin level higher than $12 \mathrm{~g} / \mathrm{dL}$ is a significant prognostic factor in survival. Neuhof et al. ${ }^{21)}$ have reported that patients with hemoglobin concentrations $>13.4 \mathrm{~g} / \mathrm{dL}$ had significantly better overall survival rates than ones with lower hemoglobin concentrations. Rades et al. ${ }^{20)}$ also reported that the best overall survival rate was achieved when the hemoglobin concentration level was between 12.1 and 14.0 $\mathrm{g} / \mathrm{dL}$ followed by levels $>14.1 \mathrm{~g} / \mathrm{dL}$ and $<12 \mathrm{~g} / \mathrm{dL}$ suggesting the existence of an optimal range of hemoglobin concentrations. Therefore, assessment of hemoglobin level before concurrent chemoradiotherapy and regular follow-up during the treatments are proposed to enhance the effect on patient prognosis.

Response to treatments has been also reported to be a prognostic factor related to survival rates. ${ }^{22,23)}$ Stahl et al. ${ }^{22)}$ reported that patients with tumors responding to treatment had a better probability of surviving, whereas the outcomes of non-responders was generally poor. We divided patients in our study into two response groups: patients with complete responses or partial responses and patients with no response or disease progression. Given the results of our study, patient prognosis in patients may be predicted according to the response to treatment.

Stage is one of the most meaningful prognostic factors in estimating survival rates including depth of tumor invasion, nodal involvement, and distant metastases. Results related to staging in our institution did not show any significance to expect the prognosis for esophageal cancer patients. However, the number of patients in our study was relatively small compared to other institutional studies. Furthermore, the TNM classification with 6th edition is simply assorted compared with recent staging system.

Esophageal cancers in men tend to have a more aggressive nature with poorer outcomes. ${ }^{1)}$ Result in our study did not show any statistical significance according to gender. However, the relatively small number of female patients in our study causes a little significance for expecting prognosis.

Herskovic et al. ${ }^{11)}$ reported a $39 \%$ rate of local recurrence after concurrent chemoradiotherapy, $7 \%$ were distant metastasis only and $5 \%$ were local recurrences with distant metastasis. In our study, local recurrence rate after complete response to treatment was $2.3 \%$, local progression was found in $39.5 \%$ of the patients, and distant metastases were reported in $9.3 \%$ of the patients. There were no patients with local recurrence and distant metastasis at the same time. The patterns of treatment failure in our study are similar with other institutional studies.

Generally, it has been found that acute complications in patients undergoing chemoradiotherapy are more severe than those of patients receiving radiation alone. These complications include esophagitis along with other common problems like nausea, vomiting, epidermitis, fatigue, and ulceration. Khurana et al. $^{24)}$ reported a $6 \%$ rate of ulceration and $21 \%$ rate of esophageal stricture among 68 patients with esophageal cancer after concurrent chemoradiotherapy. Our results showed $11.6 \%$ of esophagitis with $2.3 \%$ of ulceration and $27.9 \%$ of esophageal stricture and obstruction. In our study, small number of patients and irregular follow-up periods might effect on the difference in the results compared with other 
trials. Future studies need to examine at appropriate time with many patients group to get more reliable result.

In conclusion, the survival rates of patients with locally-advanced esophageal cancer treated with concurrent chemoradiotherapy in our study were similar to those of other institutions. Local recurrence was a main cause of treatment failure. It is suggested that further prospective studies need to be performed to improve local control.

\section{References}

1. Halperin EC, Perez CA, Brady LW. Perez and Brady's principles and practice for radiation oncology. 5th ed. New York: Lippincott Williams \& Wilkins, 2008:1131-1153

2. DeMeester TR, Barlow AP. Surgery and current management for cancer of the esophagus and cardia. Curr Probl Cancer 1988;12:243-328

3. Harrison LB, Fogel TD, Picone JR, Fischer DB, Weissberg JB. Radiation therapy for squamous cell carcinoma of the esophagus. J Surg Oncol 1988;37:40-43

4. Pearson JG. The value of radiotherapy in the management of squamous oesophageal cancer. Br J Surg 1971;58:794-798

5. Kelsen DP, Ginsberg R, Pajak TF, et al. Chemotherapy followed by surgery compared with surgery alone for localized esophageal cancer. N Engl J Med 1998;339:1979-1984

6. Arnott SJ, Duncan W, Gignoux M, et al. Preoperative radiotherapy in esophageal carcinoma: a meta-analysis using individual patient data (Oesophageal Cancer Collaborative Group). Int J Radiat Oncol Biol Phys 1998;41:579-583

7. Rich T. Chemoradiation in conservation therapy for esophageal cancer. Hematol Oncol Clin North Am 2001;15:291-302

8. Hennequin C, Maylin C. Continuous radiosensitizing chemotherapy. Pathol Biol (Paris) 1999;47:279-281

9. Cooper JS, Guo MD, Herskovic A, et al. Chemoradiotherapy of locally advanced esophageal cancer: long-term follow-up of a prospective randomized trial (RTOG 85-01). Radiation Therapy Oncology Group. JAMA 1999;281:1623-1627

10. James K, Eisenhauer E, Christian M, et al. Measuring response in solid tumors: unidimensional versus bidimensional measurement. J Natl Cancer Inst 1999;91:523-528

11. Herskovic A, Martz K, al-Sarraf M, et al. Combined chemotherapy and radiotherapy compared with radiotherapy alone in patients with cancer of the esophagus. $\mathrm{N}$ Engl $\mathrm{J}$ Med 1992;326:1593-1598

12. Smith TJ, Ryan LM, Douglass HO Jr, et al. Combined chemoradiotherapy vs. radiotherapy alone for early stage squamous cell carcinoma of the esophagus: a study of the Eastern Cooperative Oncology Group. Int J Radiat Oncol Biol Phys 1998;42:269-276

13. Zenda S, Hironaka S, Boku N, et al. Impact of hemoglobin level on survival in definitive chemoradiotherapy for T4/M1 lymph node esophageal cancer. Dis Esophagus 2008:21:195-200

14. Knocke TH, Weitmann HD, Feldmann HJ, Selzer E, Potter R. Intratumoral $\mathrm{pO} 2$-measurements as predictive assay in the treatment of carcinoma of the uterine cervix. Radiother Oncol 1999;53:99-104

15. Menon C, Fraker DL. Tumor oxygenation status as a prognostic marker. Cancer Lett 2005;221:225-235

16. Vaupel P. Prognostic potential of the pre-therapeutic tumor oxygenation status. Adv Exp Med Biol 2009;645:241-246

17. Nordsmark M, Bentzen SM, Rudat V, et al. Prognostic value of tumor oxygenation in 397 head and neck tumors after primary radiation therapy: an international multi-center study. Radiother Oncol 2005;77:18-24

18. Grigiene R, Aleknavicius E, Kurtinaitis J. Prognostic value of anemia for patients with cervical cancer treated with irradiation. Medicina (Kaunas) 2005;41:916-924

19. Langendijk $H$, de Jong $J$, Wanders $R$, Lambin $P$, Slotman B. The importance of pre-treatment haemoglobin level in inoperable non-small cell lung carcinoma treated with radical radiotherapy. Radiother Oncol 2003;67:321-325

20. Rades D, Schild SE, Bahrehmand R, Zschenker $O$, Alberti WA, Rudat VR. Prognostic factors in the nonsurgical treatment of esophageal carcinoma with radiotherapy or radiochemotherapy: the importance of pretreatment hemoglobin levels. Cancer 2005;103:1740-1746

21. Neuhof D, Neumayer F, Einbeck W, et al. Retrospective evaluation of combined modality treatment and prognostic factors in patients with esophageal cancer. Acta Oncol 2005;44: 168-173

22. Stahl M, Stuschke M, Lehmann N, et al. Chemoradiation with and without surgery in patients with locally advanced squamous cell carcinoma of the esophagus. J Clin Oncol 2005;23:2310-2317

23. Noh OK, Je HU, Kim SB, et al. Results of definitive chemoradiotherapy for unresectable esophageal cancer. J Korean Soc Ther Radiol Oncol 2008;26:195-203

24. Khurana $R$, Dimri K, Lal $P$, et al. Factors influencing the development of ulcers and strictures in carcinoma of the esophagus treated with radiotherapy with or without concurrent chemotherapy. J Cancer Res Ther 2007;3:2-7 


\title{
국소적으로 진행된 식도암에서 동시항암화학방사선치료의 결과
}

\author{
계명대학교 의과대학 동산의료원 방사선종양학교실*, 내과학교실 ${ }^{\dagger}$ \\ 변상준* · 김진희* · 김옥배* · 송홍석 ${ }^{\dagger}$
}

목 적: 국소적으로 진행된 식도암에서 동시항암화학요법 후 국소제어, 생존율, 예후인자 및 실패양상에 대해 알아 보고자 하였다.

대상 및 방법: 1999년 6월부터 2008년 8월까지 계명대학교 동산의료원에서 국소적으로 진행된 식도암으로 진단받 은 후, 근치적 목적의 동시항암화학방사선치료를 시행 받은 50 명 중 추적검사가 이루어지지 않은 2 명과 적절한 추 적검사가 이루어지지 않아 치료의 효과를 판정할 수 없는 5 명은 제외한 43 명을 대상으로 하였다. 성별 구성은 남성 39명, 여성 4명이었고 연령분포는 43세에서 78세(중앙값, 63세), TNM 병기는 IIA기 7명(16.3\%), Iㅣㄱㅣ 36명(83.7\%) 이었다. 방사선치료는 1.8 Gy씩 1일 1회, 주 5회로 방사선을 46 63 Gy (평균, $54 \mathrm{~Gy}$ )의 외부방사선을 조사하였다. 선행항암화학요법을 시행 받은 환자는 8명이었고 동시항암화학치료는 주로 5-fluorouracil, cisplatin을 3회 사용하 였다. 추적관찰 기간은 2개월에서 82 개월로 중앙값이 15.5 개월이었다.

결 과: 전체환자 43명 중에서 완전 관해는 9명(20.9\%), 부분 관해는 23 명(53.5\%), 무반응 9명(20.9\%), 진행이 2명 (4.7\%)이었다. 전체 환자의 중앙생존기간은 15 개월이었고, 2년 및 5년 전체생존율은 $36.5 \%, 17.3 \%$ 이었으며, 2년 및 5년 무병생존율은 각각 $32.4 \%, 16 \%$ 였다. 43명의 환자 중에서 22 명(51.2\%)에서 치료 실패를 보였고, 치료 실패 양상으로는 국소 재발 및 진행이 18 명(41.9\%), 원격전이가 4 명(9.3\%)이었다. 전체생존율 및 무병생존율에 영향을 미치는 인자에 대한 단변량분석상 항암화학방사선치료 시의 혈색소 수치 $(\geq 12$ vs. $<12, p=0.02 / p=0.1)$ 와 치료에 대한 반응 여부(완전관해 및 부분관해 vs. 무반응 및 병의 진행, $\mathrm{p}=0.002 / \mathrm{p}<0.0001$ )가 통계적으로 유의한 인자였 다. 다변량분석에서는 치료에 대한 반응 여부만이 통계적으로 유의한 것으로 나타났다. 환자의 나이, 성별, 병기, 흡연의 과거력, 식도 내 종양의 위치 및 선행항암화학요법의 유무에 따른 유의한 차이는 관찰되지 않았다.

결 론: 국소적으로 진행된 식도암의 동시 항암화학방사선치료 후 생존율은 다른 연구들과 유사한 수준이며 주된 재 발 양상은 국소 재발이었다. 그러므로, 국소제어율을 향상시키기 위한 추가적인 연구가 향후 필요할 것으로 생각된 다.

핵심용어: 식도암, 동시항암화학방사선치료, 생존율, 예후 인자, 실패양상 